\title{
The Impact of Telegram as a Social Network on Teaching English Vocabulary among Iranian Intermediate EFL Learners
}

\author{
Farid Ghaemi, Niloofar Seyed Golshan \\ Department of English, Faculty of Literature and Foreign Languages, Islamic Azad University of Karaj, Karaj, Iran \\ Email address: \\ fghaemi@yahoo.com (F. Ghaemi), golshanniloofar@gmail.com (N. S. Golshan) \\ To cite this article: \\ Farid Ghaemi, Niloofar Seyed Golshan. The Impact of Telegram as a Social Network on Teaching English Vocabulary among Iranian \\ Intermediate EFL Learners. International Journal of Information and Communication Sciences. Vol. 2, No. 5, 2017 , pp. 86-92. \\ doi: $10.11648 /$ j.ijics.20170205.15
}

Received: April 9, 2017; Accepted: May 11, 2017; Published: October 31, 2017

\begin{abstract}
To help students find language classes, especially vocabulary lessons more interesting in English as a Foreign Language (EFL) context, a study was conducted to investigate the effects of short massages services (SMS) via social networks on EFL learners' vocabulary learning process. To this end, an experimental approach was applied to assess the efficacy of SMS-based teaching on students' vocabulary learning. A PET proficiency test, two time-series vocabulary progress tests, and a post-test were applied to explore the effects of SMS on students' vocabulary learning process. Then the difference in mean scores was compared to answer the research question. The study has revealed that: (1) the use of SMS via social networks as a teaching tool had a positive effect on students' vocabulary learning; (2) the experimental group obtained somewhat higher scores in the post-test than in two time-series progress tests, making the difference between the progress tests and post-test significantly different; (3) the difference between the two progress tests and post-test for control group was not statistically significant; and (4) the experimental students were more differentiated than the control students, as shown by a statistically significant difference between the mean scores of both groups in post-test in favor of the experimental students.
\end{abstract}

Keywords: Vocabulary Learning, Social Networks, Mobile Assisted Language Learning (MALL)

\section{Introduction}

Vocabulary development is crucial both from a theoretical and practical point of view. Experts in the field of vocabulary development are in agreement that vocabulary is a central factor in the language learning process. It is generally recognized that a focus on strengthening vocabulary is necessary at every stage of a learner's language development (Coombe, 2011). Folse $(2003,2004)$ as well as those who championed the lexical approach and lexical syllabus in the 1980s and 1990s (Lewis, 1993, 1997; Willis, 1990; Willis \& Willis, 1989) point out that you can get by without the correct syntax or grammar, but not vocabulary.

Nowadays using technology in language teaching and learning is dominant and there is a vast body of research devoted to the effects of applying technology on Foreign Language Acquisition (FLA), but only a small number of these studies devoted to the effects of mobile phone on FLA.
Telegram is a technology widely used as a means of communication by Iranian youth today, but there are few researches in this regard (Yousefzadeh, 2012).

According to Wanger and Wilson (2005), wireless and mobile technology are growing fast and the use of mobile phones are beginning to have noticeable impacts on language teaching and learning process all over the world. These new trends have led to changes in learning forms, from traditional classroom learning to electronic learning (E-learning), ubiquitous learning (U-learning), and mobile learning (Mlearning). Among these learning forms, mobile learning is more flexible and effective than others. It can overcome the restrictions of time and space; it enables learners to study anywhere and anytime needed (Chen \& Chung, 2007). As Prenskey (2005) states, mobile phones are useful minicomputers that fit in youths' pocket, are always with them, and are nearly always on.

Generally, present study has a great potentiality to 
contribute to Teaching English as a Foreign Language from theoretical and pedagogical perspectives. Its significance could be predicted on the assumption that with a limited inclass teaching time the best way for providing language learners with a substantial learning experience is the use of mobile phone technologies. As there has been little research in Iran on mobile learning, the results of this study may offer an understanding of mobile learning, particularly vocabulary learning via social networks, Telegram.

\section{Review of Literature}

\subsection{Vocabulary Learning Activities}

According to Nation (2001), vocabulary learning activities fall into two categories: incidental vocabulary learning and intentional vocabulary learning. Each type has some characteristics and limitations which will be described as follows.

\subsubsection{Incidental Learning}

Scholars have different definitions for incidental learning. For instance, Saragi, Nation, and Meister (1978) define the incidental learning in terms of language acquisition, to be an effective way of learning vocabulary from context. Incidental vocabulary learning refers to a particular type of learning through which students learn vocabulary through extensive reading and by guessing the meaning of the new words with no specific attention to vocabulary development (Huckin \& Coady, 1999). This kind of learning provides opportunities for inferring meaning from context; learners could acquire vocabulary and read the context simultaneously. It is an individualized and more learner-based approach and the vocabulary being acquired depends on the learner's selection of reading materials. Schmidt (1990) also points out that incidental learning is a passive process which can happen when the focus of attention is on some relevant features of input.

In a research, Hill and Laufer (2003) studied the effects of computer-based dictionaries on EFL learners' incidental vocabulary learning. The research findings revealed that use of computer-based dictionaries could cause more incidental learning activities for Chinese EFL university students. In this regard, Kukulska-Hulm and Shield (2007), mention that recent technologies gave rise to mobile assisted vocabulary learning activities which take advantages of mobile phone unique characteristics such as its flexibility, immediacy, content sensitivity, portability, social interactivity, connectivity, and individuality. Some researchers (Crowe \& van't Hooft, 2006; Klopfer, Squire, \& Jenkins, 2002; Kukulska-Hulm \& Shield, 2007) have experimented the second language learners' vocabulary learning using mobile technologies for prescribed vocabulary learning tasks. They have also tested some personalized learning systems in order to enhance language learners' vocabulary learning through a short period of time (Chen \& Chung, 2007; Stockwell, 2007; Thornton \& Houser, 2005).

\subsubsection{Intentional Learning}

The intentional vocabulary learning refers to activities which aim at predominant vocabulary development (Nation, 2001). Intentional vocabulary learning is a learning process based on synonyms, antonyms, word substitution, multiple choice, scrambled words and crossword puzzles, regardless of context so it could not be so effective since it encourages learners to rote learning (Ahmad Jeddah, 2012). Students cram the word meanings into their minds but without undergoing cognitive process and this means learning just a few words so they get a limited set of words to transform into active process.

On the other hand, Ahmad Jeddah (2012) continues that through reading texts the students could be more productive using the guessing strategy. Guessing enables learners to infer meaning of the word and begin to understand it gradually. Guessing is a useful strategy for both high proficiency and low proficiency level students since it increases their focus on the meanings and then the acquired vocabularies could be retained easily.

Stahl and Fairbanks (1986) analyzed nearly one hundred independent studies and concluded that intentional vocabulary learning process is a useful adjunct to natural process of learning from context. Additionally, Paribakht and Wesche (1993) cited in Yali (2010) investigated that contextualized learning through reading could be effective but this is superior when the intentional learning is added to it. They remark that reading for inferring meaning contributes to the vocabulary knowledge but it could be more effective when specific vocabulary exercises are provided.

\subsection{The Impact of Using Mobile Technologies for Teaching and Learning}

The findings of the Attewelle, Savill-Smith, and Douch's (2009) practitioner-led research suggest that using mobile technologies in teaching and learning has some effects:

1) It can encourage and support learning at any time and in any place including home, school, or college, etc.

2) It would make learning more convenient, accessible, inclusive and sensitive to learners' needs.

3) It makes learning more interesting, enjoyable and more attractive.

4) It engages both non-traditional learners and those not succeeded in traditional learning in learning process giving a sense of self-confidence and self-esteem to learners.

5) It overcomes the digital barrier between those learners who have broadband access at home and those who do not.

6) Finally, it helps teachers to provide various learning activities to suit learners with different learning styles.

Attewelle et al. (2009) argue that there are some significant caveats in mobile learning. They demonstrated that mobile learning is not a single solution for supporting learning. There are some other technology-pedagogy combinations which may or may not be suitable for this purpose. 
According to Begum (2011), in the last decade, researchers' attention has been drawn to both m-Learning for language study, and to using SMS for learning generally. Ownership of a mobile device has a significant role in implementing m-Learning technologies among learners (Corlett, Sharples, Chan \& Bull, 2004 cited in Begum, 2011). In recent years, mobile phones are widely used by young people in Asia, Europe, America, and South Africa (Green, 2007). SMS, as a popular mobile phone application, provides an appropriate source for the deployment of m-Learning environment among university students. Many researchers have focused their research on SMS-based m-Learning. Petrova (2007) conducted a research on evaluating SMSbased revision. Previous research on the ownership and usage of SMS among undergraduate students at AUT (Auckland University of Technology) in New Zealand has justified the feasibility of deploying m-learning using SMS.

Language learning has become more popular and more important in "the global village" for both minors and adults (Morgan \& Ramanathan, 2005). Mobile devices, such as Personal Device Assistant (PDA)s, MP3/iPod players and mobile phones, have been involved in assisting language learning making it effective and flexible (Houser, Thornton \& Kluge, 2002). Meanwhile, research efforts have been made to investigate emerging issues. Cooney and Keogh (2007) investigated how mobile phones and iPods assisted Irish language learning. Sixty nine students aged 14 to 15 and their teachers were recruited as participants. Positive feedback from both learners and teachers indicated that mobile technologies would be confidently used as learning tools.

\section{Method}

\subsection{Research Question}

In order to achieve the purpose of the study, the following research question was formulated:

Does the use of social networks have any effect on learning vocabulary of Iranian upper intermediate EFL learners?

\subsection{Research Hypothesis}

In order to answer the research question, the following null hypothesis will be tested:

$\mathrm{H}_{0}$ : The use of social networks has no effect on learning vocabulary of Iranian upper intermediate EFL learners.

\subsection{Participants}

The population selected for this experimental study was EFL learners of language institute. Two of the upperintermediate classes were selected to be experimental group and control group. Both groups consisted of a total of 60 students: 30 experimental group and 30 control group. Both male and female students participated in the study. They were all aged between 13 and 16 .

A proficiency test was administered to both groups at the same time to ensure the homogeneity of the participants. The results proved their homogeneity. Experimental group received the words on their mobile phones via social networks while the control group was given the same word group on paper. The teacher for both groups was the same.

\subsection{Data Collection Iinstruments}

The data used in the present study was the message sent using social networks to the experimental group participants. The messages included the word items which were selected from the textbook Passages1. Around 140 words were chosen based on the objectives of the study and were classified. Twice a week, the messages containing 15 word items with the meaning of word and an example sentence related to that word were sent to the participants by the researcher. At the end of the experiment almost 100 words were sent to the experimental group students.

In order to answer the research question and compare and assess the subjects' vocabulary learning, two time-series progress tests of vocabulary were developed and administered. The words used in the study were selected from the textbook Passages 1 which is an advanced level book. Three tests based on the taught words were designed by the researcher to see the students' performance during the experiment and investigate the role of social networks in vocabulary teaching and learning process.

\subsection{Study Procedure}

This study recruited 60 homogeneous learners. In order to have homogeneous learners a PET as a homogenizing test was administered to all participants to analyze the test results an independent samples t-test was used. Each participant was randomly assigned to one of the two groups; so there were a control group and an experimental group. Both groups were given the word items selected based on the objectives of the study but in order to make sure that the selected words were appropriate and the participants in both groups were not familiar with word items a pilot study was conducted. In this study a test containing 140 words chosen from the textbook Passages 1 was administered to a group of 15 students other than the main groups of the study. They were at the same level of proficiency, upper-intermediate, as the main participants of the study.

Furthermore, in order to make sure of the reliability of tests, it was calculated through KR-21 method which turned out to be low so 20 questions out of 140 were deleted and consequently reliability became 0.85 . Then, the treatment began based on the results gained from pilot study which proved that the pilot group students were unfamiliar with selected word items. The experimental group received words on their mobile phones via social networks, whereas the control group was given the same group of words on papers.

Data was collected from each of the two groups during their normal class times. First, participants met with the researcher. They were given a brief introduction to the project, its objectives and its method. The point which should be indicated is that the control group received no treatment 
which was receiving word items on the phone and should study the words on receiving papers. Whereas, The participants in the experimental group were required to study the words they received via social networks containing the words, their meanings and an example of the word used in the sentence. The advantage of this group was ease of access to the words wherever they wanted. They could read the words on their free times on their way to school or home. Two progress tests were administered with an interval of two weeks to see the students' performance. The reliability of each test was calculated through KR-21 and the results of this calculation were; 0.80 for progress test 1 , and 0.82 for progress test 2 . Then a post-test was designed and administered to compare the performance of both groups during the treatment. The same as other tests, the post-test contained four types; multiple choice items, fill in the blanks, matching words and cloze test. All items had four choices; one as correct answer and the other three as distracters. The scoring was the same as other tests and the reliability of the test was administered using KR-21 which was 0.81. To answer the research question, all test results were assessed and analyzed using SPSS.

\subsection{Data Analysis}

In order to measure the effects of SMS on students' vocabulary learning, the following research question was raised:

Does the use of social networks have any effect on learning vocabulary for Iranian upper intermediate EFL learners?

\section{Results}

\subsection{Preliminary Analysis: Determining the Students' Homogeneity in Terms of the PET}

The degree of homogeneity between the experimental and control group was statistically determined using one way analysis of variance for the continuous variable of the PET.

Table 1. The degree of homogeneity between the experimental and control group.

\begin{tabular}{lllll}
\hline Group & N & Mean & SD & Std. Error Mean \\
\hline EX & 30 & 81.2598 & .89779 & .23009 \\
CG & 30 & 79.7304 & 2.53956 & 1.31210 \\
K-R21 & .87 & & & \\
\hline
\end{tabular}

To check the significance of the mean differences, an independent t-test was run. As it is shown, the mean differences of the scores of the groups in PET is 1.52 .

Table 2. The mean differences of the scores of the groups in PET.

\begin{tabular}{|c|c|c|c|c|c|c|c|}
\hline Levene'sTest for Equality of Variance & $\mathbf{F}$ & Sig. & $\mathbf{T}$ & DF & Sig.(2-tailed) & Mean Difference & Std. Error Difference \\
\hline Equal variances assumed & .198 & .578 & -.077 & 58 & .795 & -.12658 & 1.36950 \\
\hline Equal variances not assumed & & & -.077 & 57.031 & .795 & -.12658 & 1.36950 \\
\hline
\end{tabular}

As it is depicted in this table, the Levene's Test for Equality of Variance was used to compare the mean differences of two groups. the F-observed value for comparing the mean scores of the participants of two groups in PET $(F(2,58)=.198, P$ $=.795 \geq 0.05)$ denoted the significant differences between the mean scores of experimental and control group. It can be concluded that they were at the same level of proficiency and hence, homogeneous.

\subsection{Repeated Measures ANOVA for Detecting Overall Difference Between Mean Scores}

In order to see whether the difference between the control group and the experimental group was meaningful or not, the ANOVA test (an analysis of variance) used.

Table 3. The difference between the control group and the experimental group.

\begin{tabular}{ll}
\hline Within-Subjects Factors & \\
\hline Measure: MEASURE_experimental & \\
\hline Experimental & Dependent Variable \\
\hline 1 & prt1 \\
2 & prt2 \\
3 & $\mathrm{Pt}$ \\
\hline
\end{tabular}

Prt: progress test

Pt: post-test

Based on the selected model, the mean scores of the participants in all three tests were calculated to examine the suitability of the model.

Table 4. The mean scores of the participants.

\begin{tabular}{lllll}
\hline Group & N & Mean & SD & Std. Error Mean \\
\hline Prt1 & 30 & 41.0667 & 6.27747 & 1.21391 \\
Prt2 & 30 & 49.6000 & 7.11288 & 1.29863 \\
Pt & 30 & 52.9667 & 4.97915 & .90906 \\
\hline
\end{tabular}

A glance at this table reveals that the experimental group shows an increase in vocabulary learning over time. In order to test the research hypothesis of the effects of the social networks on students' vocabulary learning, a Multivariate Test was conducted.

Table 5. To the results of Multivariate test.

\begin{tabular}{lllc}
\hline Effect & F & Error. Df & Sig. \\
\hline Pillai's Trace & $1.036 \mathrm{E} 2^{\mathrm{a}}$ & 28.000 & .000 \\
Wilks' Lambda $^{\mathrm{a}}$ & $1.036 \mathrm{E} 2^{\mathrm{a}}$ & 28.000 & .000 \\
Hotelling's & $1.036 \mathrm{E} 2^{\mathrm{a}}$ & 28.000 & .000 \\
\hline
\end{tabular}

According to the results of Multivariate test, as Sig $=.000$, so there was a significant difference in students' performance in experimental group, $F=1.036, p \leq .05$, Wilks $s^{\prime}=.119$. Here Wilks' V is near 0 , so it is acceptable. The results for all four values indicate a positive effect $(\mathrm{sig}=.000)$ of the social networks on experimental group vocabulary learning during time. In order to test the hypothesis that the variances of the 
differences are equal the Mauchly's Test for Sphericity was applied.

Table 6. Mauchly's Test for Sphericity of Experimental Group.

\begin{tabular}{llll}
\hline Mauchly's W & Df & Sig. & Epsilona Greenhouse-Geisser \\
\hline 0.770 & 2 & .026 & 0.813 \\
\hline
\end{tabular}

As the Sig $=.026, \mathrm{p} \leq .05$, so the Mauchly's Test for Sphericity is statistically significant. Therefore, it rejects the null hypothesis and we must accept the alternative hypothesis that the variances between levels were significantly different. We can see from our earlier table that, for our data set, the estimated epsilon ( $\varepsilon$ ) using the Greenhouse-Geisser method is 0.813 .

The same analyses were done to evaluate the control group performance through the experiment. The results are shown as follows.

Table 7. The evaluation of the control group performance.

\begin{tabular}{ll}
\hline Measure: MEASURE_Control \\
\hline Control & Dependent Variable \\
\hline 1 & Prt1 \\
2 & Prt2 \\
3 & $\mathrm{Pt}$ \\
\hline
\end{tabular}

Prt: progress test

Pt: post-test

Table 8. Descriptive statistics for the three levels of the independent variables.

\begin{tabular}{lllll}
\hline Group & N & Mean & SD & Std. Error Mean \\
\hline Prt1 & 30 & 38.2333 & 6.31191 & 1.15239 \\
Prt2 & 30 & 38.7333 & 6.82760 & 1.24654 \\
Pt & 30 & 38.2667 & 6.51753 & 1.18993 \\
\hline
\end{tabular}

This table provides basic descriptive statistics for the three levels of the independent variables. From this table it can be seen that the mean for control group had not significantly increased from progress test 1 to progress test 2 and then to the post-test. Therefore, the control group participants did not show a significant progress through experiment. In order to test the hypothesis on the effects of the paper-based teaching on control group students' vocabulary learning a Multivariate Test was conducted.

Table 9. The results of Multivariate test.

\begin{tabular}{llll}
\hline Effect & F & Error. Df & Sig. \\
Pillai's Trace & $1.297^{\mathrm{a}}$ & 28.000 & .289 \\
Wilks' Lambda & $1.297^{\mathrm{a}}$ & 28.000 & .289 \\
Hotelling's & $1.297^{\mathrm{a}}$ & 28.000 & .289 \\
\hline
\end{tabular}

According to the results of Multivariate test in this table, as $\mathrm{Sig}=.289$, so there was no significant difference in students' performance in control group, $F=1.297, p \geq .05$, Wilks' $V=.915$. These results confirmed that paper-based teaching did not reach conventional levels of statistical significance and had no significant effect on control group participants' vocabulary learning process. As mentioned for the experimental group, a Mauchly's Test for sphericity also conducted to confirm hypothesis that the variances of the differences are equal.

Table 10. The results of Multivariate test.

\begin{tabular}{llll}
\hline Mauchly's W & Df & Sig. & Epsilona Greenhouse-Geisser \\
\hline 0.866 & 2 & .134 & 8.882 \\
\hline
\end{tabular}

The significance value for control group performance through treatment is $\mathrm{Sig}=.134, p \geq .05$, so it is concluded that there was no significant difference between variances.

\section{Results and Discussion}

The findings of the present study were in line with the findings of Khazaie and Dastjerdi (2011), who suggested that regarding the mobile phone potentials in the realm of teaching and learning vocabulary, we should go beyond it and apply these technologies in teaching and learning other skills and sub-skills too. The findings also echo the findings of the study conducted by Levy and Kennedy (2005), who concluded from their study that, mobile phones have many advantages in the field of learning. It can help learners to improve their literacy and numeric skills and also helps them to recognize their existing abilities. It encourages both independent and collaborative learning experiences. Helps students to recognize their difficulty areas for which they need help and support. Mobile phones as Levy and Kennedy stated are language assistant since they can provide some references and instructions to support learners.

In a study Alemi and Lari (2012) investigated the effects of social networks on Iranian university students' vocabulary learning. The 320 headwords of the Academic Word List sent via social networks to the students in experimental group during the 16 weeks of experiment. Control group learned the words using a dictionary. At the end of the experiment the results of the post-test showed that experimental group outperformed the control group and the experimental group students had a positive attitude towards using SMS in vocabulary learning.

Similarly, Lu (2008) explored the effectiveness of using social networks in vocabulary lessons. The lessons were sent via social networks to the students and to investigate the effects of this learning tool, a post-test administered. The findings of the study proved the positive role of social networks on students' learning process.

Coony and Keogh (2007) conducted a study to investigate role of mobile phones and iPods in teaching Irish vocabulary to language learners. 69 students participated in this study aged 14 to 15 . The results of the study and the feedback from students and teachers were analyzed. These results proved the effectiveness of the mobile phone as a learning tool.

The final step now is to examine the major research question set for the present study, which was: "Does the use of social networks have any effect on teaching vocabulary to Iranian upper intermediate EFL learners?" the substantial difference between the two progress tests and the post-test scores for the experimental group permits us to confirm that 
the SMS-based teaching did have a strong positive effect on the students' vocabulary learning. Hence, the null hypothesis "The interactive short message service has no significant effect on EFL learners' vocabulary improvement" is completely rejected because the results showed that the SMS technology had a strong positive effect on the vocabulary learning of the experimental group.

\section{Conclusion}

As discussed in detail, different factors affect Iranian EFL learners' vocabulary learning in the class. Among these factors is the dominance of the traditional methods. A possible answer to this problem would be application of mobile learning and particularly the SMS based learning environments. After the teaching vocabulary via SMS in the present study, the experimental group outperformed the control group with a statistically significant difference in mean scores. Such result yielded an evidence of the positive effects of the SMS on learners' vocabulary learning ability. Therefore, the present study recommends effective use of SMS in language teaching and learning.

\section{References}

[1] Ahmad Jeddah, J. (2012). Intentional vs. Incidental Vocabulary Learning. ELT Research Journal, 1 (1), 71-79.

[2] Attewell, J., Savill-Smith, C., \& Douch, R. (2009). The impact of mobile learning, Examining what it means for teaching and learning. Retrieved from:

http://www.caryloliver.com/Library/ImpactOfMobileLearning. pdf.

[3] Begum, R. (2011). Prospect for cell phones as instructional tools in the efl classroom: a case study of Jahangirnagar University, Bangladesh, Canadian Center of Science and Education. English language Teaching, 4 (1), 105-116.

[4] Chen, C., \& Chung, C. (2007). Personalized mobile English vocabulary learning. Computers \& Education, 51 (2), 624647.

[5] Begum, R. (2011). Prospect for cell phones as instructional tools in the efl classroom: a case study of Jahangirnagar University, Bangladesh, Canadian Center of Science and Education. English language Teaching, 4 (1), 105-116.

[6] Chen, C., \& Chung, C. (2007). Personalized mobile English vocabulary learning. Computers \& Education, 51 (2), 624 647.

[7] Coombe, C. (2011). Assessing vocabulary in the language classroom. In D. Anderson \& R. Sheehan (Eds.), Focus on Vocabulary: Emerging Theory and Practice for Adult Arab Learners (pp. 111-124). United Arab Emirates, Dubai: HCT Press.

[8] Cooney, G., \& Keogh, K. A. (2007). Use of Mobile Phones for Language Learning and Assessment for Learning, A Pilot Project. The 6th international conference on mobile learning. Melbourne, Australia.

[9] Crowe, A., \& Van't Hooft, M. A. H. (2006). Technology and the prospective teacher: Using handheld devices in social studies education. Current Issues in Technology and Teacher Education, 6 (1), 1-25.

[10] Folse, K. (2003). The Influence of L2 research on vocabulary learning materials. Plenary presented at MLI Teacher2Teacher Conference, Abu Dhabi, United Arab Emirates.

[11] Folse, K. (2004). Vocabulary myths: Applying second language research to classroom teaching. Ann Arbor, MI: The University of Michigan Press.

[12] Green, A. (2007). Washback to learning outcomes: a comparative study of IELTS preparation and university presessional language courses, 14 (1), 75-97.

[13] Houser, C., Thornton, P., \& Kluge, D. (2002). Mobile learning: Cell phones and PDAs for education. Proceedings of the International Conference on Computers in Education, Australia, ICCE 2002, 1148-1149.

[14] Klopfer, E., \& Squire, K., Jenkins, H. (2002). Environmental Detectives - The development of an Augmented Reality Platform for Environmental Simulations. Educational Research Technology and Development. Los Alamitos, CA.: IEEE Computer Society Publications.

[15] Kukulska-Hulme, A. \&, Shield, L. (2007). An overview of mobile assisted language learning: From content delivery to supported.

[16] Collaboration and interaction. European Association for Computer Assisted Language Learning 20 (3), 271-289.

[17] Laufer, B. (1998). The development of passive and active vocabulary in a second language: Same collaboration and interaction. European Association for Computer Assisted Language Learning 20 (3), 271-289.

[18] Lewis, M. (1997). Pedagogical implications of the lexical approach. In J. Coady \& T. Huckin (Eds.), Second language vocabulary acquisition (pp. 255-270). Cambridge: Cambridge University Press.

[19] Morgan, B., \& Ramanathan, V. (2005). Critical literacies and language education: Global and local perspectives. Annual Review of Applied Linguistics, 25, 151-169. dCambridge University Press.

[20] Petrova, K. (2007). Mobile Learning Using SMS: A Mobile business application. Retrieved from: http://www.smartmobs.com/archives/002910.Html or different? Applied Linguistics, 12, 255-71.

[21] Prenskey, M. (2005). What can You Learn from a Cell Phone? Almost Anything! The Innovative Gateway 1. Retrieved from: $\mathrm{http} / / / \mathrm{www}$. innovateonline.info/index.php.

[22] Schmidt, R. (1990). "The role of consciousness in second language learning". Applied Linguistics, 11(2), 24. Stahl, S., \& Fairbanks, M. (1986). Effects of vocabulary instruction: A model-based meta-analysis. Review of Educational Research.

[23] Thornton P., \& Houser. C. (2005). Using mobile phones in English education in Japan. Journal of Computer Assisted Learning, 21, 217-228.

[24] Wanger, E. D., \& Wilson, P. (2005). Disconnected: why learning professional need to care about mobile learning, American Society for Training and Development 59 (12), 40-43. 
[25] Willis, D. (1990). The lexical syllabus: A new approach to language teaching. London: Collins.

[26] Willis, J., \& Willis, D. (1989). Collins COBUILD English course. London: Collins COBUILD.

[27] Yali, g. (2010). L2 Vocabulary Acquisition Through
Reading-Incidental Learning and Intentional Learning, 33 (1), 25-48.

[28] Yousefzadeh, M. (2012). Multimedia messaging service (MMS) VS. short message sending (SMS) and second language learners' vocabulary. Journal of Educational And Instructional Students in The World, 2 (4), 89-99. 